\title{
Short Sexual Well-Being Scale- a cross-sectional validation among transgender and cisgender people
}

\begin{abstract}
BACKGROUND
Sexual well-being is often mistakenly operationalized simply as sexual satisfaction. The concept of sexual wellbeing has been often used as an umbrella term for positive aspects of sexuality, apart from its negative spheres. A new concept of sexual well-being was proposed in line with the World Health Organization (WHO) definition of sexual health. The definition tried to enrich the concept of sexual well-being, but it did not solve the problem of its operationalization. The aim of this study was to verify the psychometric properties of the new scale measuring the concept of sexual well-being.
\end{abstract}

\section{PARTICIPANTS AND PROCEDURE}

Two separate studies were conducted for the psychometric validation of the Short Sexual Well-Being Scale (SSWBS). This was because the first study on a group of transgender people was characterized by a smaller than recommended sample for confirmatory factor analysis. On this basis, a second study was conducted on a group of cisgender people. The study on a sample of transgender people $(N=111)$ verified the psychometric properties of the 4-point version of the scale. In the study on the cisgender sample $(N=211)$, it was decided to verify the psychometric properties of the 7-point version of the scale and verify whether a bigger response scale would have a positive effect on the reliability of the questionnaire.

\section{RESULTS}

The confirmatory factor analysis, reliability analysis using alpha and total omega coefficients, and two measures of validity (content and criterion validity) were applied. The results indicated that the SSWBS had good psychometric properties.

\section{CONCLUSIONS}

Overall, the presented scale shows good psychometric properties. Both versions of the scale can be used in the quantitative research, but it is recommended to use the 7-point version of the scale. The SSWBS is one of the first questionnaires constructed in accordance with the sexual well-being concept.

\section{KEY WORDS}

sexual satisfaction; transgender; psychometric validation; sexual well-being; cisgender

ORGANIZATION - Department of Health Psychology and Quality of Life, Institute of Psychology, Opole University, Opole, Poland

Authors' Contributions - A: Study design - B: Data collection - C: Statistical analysis - D: Data interpretation .

E: Manuscript preparation · F: Literature search · G: Funds collection

CORRESPONDING AUTHOR - Rafał Gerymski, Department of Health Psychology and Quality of Life, Institute of Psychology, Opole University, 1 Staszica Square, 45-052 Opole, Poland, e-mail: rafal.gerymski@uni.opole.pl

TO CITE THIS ARTICLE - Gerymski, R. (2021). Short Sexual Well-Being Scale - a cross-sectional validation among transgender and cisgender people. Health Psychology Report, 9(3), 276-287. https://doi.org/10.5114/hpr.2021.102349

RECEIVED 06.07.2020 • REVIEWED 14.07.2020 • ACCEPTED 04.11.2020 • PUBLISHED 31.12.2020 


\section{BACKGROUND}

Sexuality is an important topic in the functioning of every human being. Studies on the sexuality of transgender people are very specific. Researchers usually limit themselves to studying the sexual health of transgender people working in the sex industry (Nemoto et al., 2012; Poteat et al., 2015; Reisner et al., 2009) or the impact of sex reassignment surgery and hormone replacement therapy on the well-being of transgender people (Gerymski, 2017; Kuiper \& Cohen-Kettenis, 1988). There is a lack of research focusing on sexuality of transgender people from the eudaimonistic view of well-being. The situation of transgender people in Poland shows that the levels of their subjective well-being are lower than those of cisgender people (Gerymski, 2018). This prompts one to reflect on the subject of sexual well-being in transgender people. Many researchers focus on the topic of transphobia (Lombardi, 2009) or sex reassignment (Kuhn et al., 2009) as predictors of transgender people's well-being and quality of life. There is a lack of research taking into account the concept of sexual well-being in transgender people which has a much wider range of predictors than just the process of sex reassignment or sexual discrimination. One reason for the small amount of research on sexual well-being may be the problem of incorrect or incomplete operationalization of this concept.

Sexual well-being is often mistakenly operationalized simply as sexual satisfaction (Leavitt et al., 2019; Öberg et al., 2002; Stephenson \& Meston, 2010). Equating sexual wellbeing with sexual satisfaction is wrong, because sexual satisfaction only reflects the hedonistic aspect of human sexuality. Sexual wellbeing has been defined as the perceived quality of our sexuality, sexual life, sexual relationships and sexual compatibility with the partner (Graf \& Patrick, 2014; Štulhofer et al., 2019). It refers to the cognitive and emotional evaluation of human sexuality. It is also defined as emotional and physical satisfaction of sexual relationships and sexual health (Bancroft et al., 2011; Laumann et al., 2006; Rosen \& Bachmann, 2008).

The concept of sexual well-being has often been used as an umbrella term for positive aspects of sexuality, apart from its negative spheres (Štulhofer et al., 2019). The presented definition of sexual well-being is not fully correct for four reasons. Firstly, it does not fully comply with the World Health Organization (WHO) definition of sexual health. The WHO defines sexual health as a state of well-being in relation to sexuality in four spheres: physical, emotional, mental and social (World Health Organization, 2006). The presented sexual well-being definitions seem to focus on satisfaction in the physical and psychological spheres, bypassing the social aspects of sexuality. Sexuality in the social sphere is related with expressing human sexuality or the possibility of realizing our sexual fantasies without compromising the well-being of the community - which is important for people with sexual preferences that are against the law. Secondly, the given definitions of sexual well-being are only in line with the definition of hedonistic well-being (focused on the pleasure attainment and pain avoidance) and not eudaimonic well-being (reflecting our selfrealization and fulfilment; Ryan \& Deci, 2001). Thirdly, most of the definitions of sexual well-being try to focus only on the positive aspects of sexuality. This is not in line with accepted definitions of well-being, which also include negative aspects of our functioning - such as negative emotions and ubiquitous distress (Ryan \& Deci, 2001). Finally, sexual well-being definitions seem to discriminate against those who often change their sexual partner or people single by choice, who can also lead a very satisfying life (Ochnik \& Slonim, 2020). Based on the presented criticism of the sexual wellbeing definitions, it is recommended to revise this concept in line with the WHO's sexual health definition and the negative aspect of sexuality. Figure 1 presents the new proposed concept of sexual well-being.

\section{Figure 1}

Proposed concept of sexual well-being

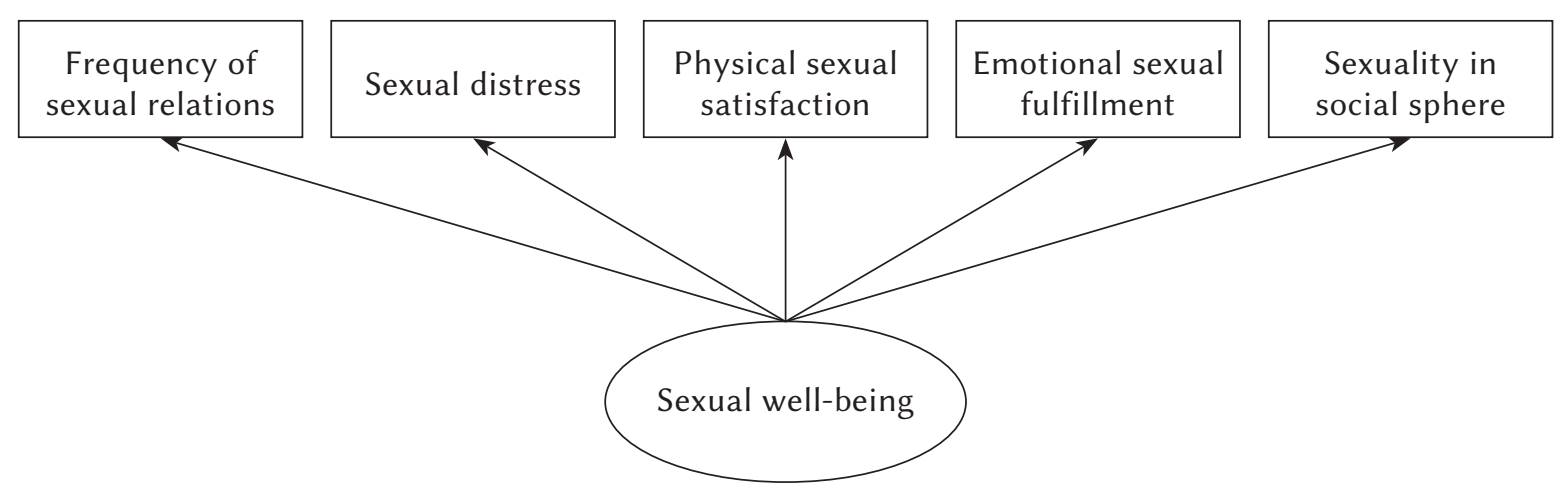


Frequency of Sexual Relations can be expressed in the form of a subjective assessment of the frequency of sexual contacts and the satisfaction associated with it (and not just a number). It is not limited to adequate compatibility with the partner, in order to not be discriminatory in the case of people who often change sexual partners or are single by choice and even people for whom a low frequency of sexual contact can be satisfactory. Sexual Distress represents negative emotions related to sexuality. Physical Sexual Satisfaction reflects hedonistic sexual satisfaction related to the feeling of orgasm and other pleasant feelings regarding the physical aspect of human sexuality. Emotional Sexual Fulfillment is related to the sense of accomplishment, different from hedonistic sexual satisfaction. Finally, Sexuality in Social Sphere represents the forgotten social sphere of sexual health. It can be expressed in the form of realizing one's sexual preferences and fantasies related to a person's sexual identity.

\section{THE CURRENT STUDY}

The new definition tries to enrich the concept of sexual well-being, but does not solve the problem of its operationalization. There are no questionnaires adapted to Polish dealing with sexual well-being. There is a lack of psychological scales measuring aspects of sexual well-being other than hedonistic sexual satisfaction. There are also no validated scales in Polish that deal with the sexual sphere of transgender people. The researcher's goal was to create a short scale for pilot studies, which would verify a broader spectrum of human sexuality than just hedonistic sexual satisfaction. The study aimed to verify the psychometric properties of the Short Sexual Well-Being Scale (SSWBS).

\section{PARTICIPANTS AND PROCEDURE}

Two separate studies were conducted for the psychometric validation of the SSWBS. This was because the first study on a group of transgender people was characterized by a smaller than recommended sample for confirmatory factor analysis (CFA). On this basis, a second study was conducted on a group of cisgender people. The study on a sample of transgender people verified the psychometric properties of the 4-point version of the scale. In the study on cisgender sample, it was decided to verify the psychometric properties of the 7-point version of the scale, and verify whether a bigger response scale would have a positive effect on the reliability of the questionnaire. The present study was carried out in accordance with the guidelines of the Bioethics Committee of the University of Opole.

\section{STUDY 1: TRANSGENDER PEOPLE}

The first study involved 111 transgender people recruited through LGBTQ+ support groups in Poland. The sample included 22 transgender women and 89 transgender men aged between 19 and 42 $(M=23.07, S D=4.06)$. The disproportion between transgender women and transgender men is consistent with previous Polish studies on a group of transgender people (Gerymski, 2018). Only four transgender people $(3.60 \%)$ stated that they had undergone sex reassignment surgery associated with their genitals (e.g. panhysterectomy, neophalloplasty, metoidioplasty, vaginoplasty), three $(2.70 \%)$ stated that they had undergone chest correction surgery (e.g. mastectomy, breast enlargement etc.) and twenty-two $(19.82 \%)$ stated that they were undergoing hormone replacement therapy. No other sociodemographic variables were tested. In this study, the validity and reliability of the created scale were verified. All questionnaires described in the method section were used in the study.

\section{STUDY 2: CISGENDER PEOPLE}

The second study involved 224 cisgender people. The results of 13 people were excluded from the analysis due to missing data. Eventually 211 cisgender people recruited via the snowball sampling method took part in this study. The sample included 120 cisgender women and 91 cisgender men aged between 18 and $56(M=22.89, S D=5.10)$. No other sociodemographic variables were tested. This study was only intended to verify the internal consistency and the reliability of the created scale. Only the SSWBS was used in this study.

\section{METHODS}

Four scales were used in the entire research project. The author's tool was the Short Sexual Well-Being Scale (SSWBS). The SSWBS contains five items measuring the level of sexual well-being. Two versions of the scale were created: 4-point and 7-point versions. The Satisfaction with Life Scale (Diener et al., 1985) was taken as the benchmark in the SSWBS creation process. The aim of the psychometric validation was the Polish version of the scale. Scale items translated into English can be found in Appendix 1. Original items in Polish can be found in Appendix 2.

Three questionnaires were used to verify the validity of the scale. They represented constructs related to sexual well-being - self-esteem (Mastro \& Zimmer-Gembeck, 2015), life satisfaction (Stephenson \& Meston, 2010) and sexual satisfaction (Štulhofer et al., 2019). 
Self-Esteem Scale. Rosenberg's Self-Esteem Scale (SES; Rosenberg, 1979) was used. SES is a 10-item scale on a 4-point answer scale, ranging from 1 (I definitely agree) to 4 (I definitely disagree). The SES measures a global level of self-esteem. In this scale, a higher SES score means higher self-esteem. In the present study, SES was characterized by good reliability (Cronbach's $\alpha=.90$, McDonald's $\omega=.91$ ).

Satisfaction with Life Scale. Life satisfaction was measured with the Satisfaction with Life Scale (SWLS; Diener et al., 1985). It is a 5-item questionnaire on a 7-point scale, ranging from 1 (I strongly disagree) to 7 (I completely agree). The SWLS measures one aspect of subjective well-being - life satisfaction. In the SWLS, a higher score means higher life satisfaction. In the present study, the questionnaire showed good psychometric properties (Cronbach's $\alpha=.89$, McDonald's total $\omega=.90$ ).

Sexual Satisfaction Questionnaire. Nomejko's (2010) Sexual Satisfaction Questionnaire (org. Kwestionariusz Satysfakcji Seksualnej) was also used. The scale measures only the hedonistic aspect of human sexuality - sexual satisfaction. It includes questions such as: "Sex for me is a source of pleasure" or "I'm afraid I'm not satisfying my sex partner". It is a 10-item questionnaire rated on a 4-point Likert scale, ranging from 1 (it is not like that) to 4 (it is like that). In this scale, a higher score means higher sexual satisfaction. In the present study, this tool was characterized by good reliability (Cronbach's $\alpha=.86$, McDonald's $\omega=.87$ ). To the author's knowledge, Nomejko's scale questions have not been published in any scientific journal. The scale was shared with the author of this manuscript many years before carrying out the study presented in this manuscript.

\section{RESULTS}

\section{CONFIRMATORY FACTOR ANALYSIS}

The present study tried to validate two versions of the SSWBS - 4-point and 7-point versions of the questionnaire. Usually 4-point versions of the scale, due to the small number of possible answers, are treated as categorical scales. In that case, the categorical confirmatory factor analysis (CCFA) using the WLS (weighted least squares) estimator should be used. In this study, CFA with the ML (maximum likelihood) estimator was used for both versions of the scale. This choice was made based of the characteristics of the obtained data.

Data regarding the 4-point version of the scale were obtained from a relatively small sample of transgender people. Simulations show that methods based on the WLS estimator perform worse on small sample sizes (where $N<200$; Flora \& Curran, 2004; Katsikatsou et al., 2012; Koğar \& Koğar, 2015;
Li, 2016). The ML estimator method is usually used when the distribution of the obtained data is similar to normal distribution. In the present study, the values of skewness and kurtosis of both versions of the SSWBS did not exceed the range between -2 and 2 , which indicates a low asymmetry of the studied distributions (Kim, 2013). It was decided to use the ML estimator because it is more robust in the case of low asymmetry of the latent variable's distribution (Muthén \& Kaplan, 1985). Finally, it was decided to use the CFA with the ML estimator for the validation of both versions of the scale in order to be able to make a direct comparison of the values of the model fit coefficients. Although the presented 4-point scale should be treated as categorical, the use of CFA with the ML estimator is justified (Rhemtulla et al., 2012).

The CFA showed an acceptable goodness of fit of the one-factor models of the 4-point and 7-point versions of the scale. Based on modification indices, error covariances were set within the two items -3 and 4 . This was considered correct due to the semantic similarity of the identified items. This allowed better RMSEA and SRMR coefficients to be obtained for both versions of the scale. For detailed information, see Table 1.

Factor loadings analysis for the 4-point version of the scale showed that item 2 had a lower loading than other items from the SSWBS. Removing this item lowered the goodness of fit indicators, so it was decided to keep that item for further analyses. This problem did not occur for the 7-point version of the scale tested on a much larger sample. All other loadings exceeded the .40 value. Table 2 contains unstandardized and standardized factor loadings for the proposed models.

\section{MEASUREMENT INVARIANCE ACROSS GROUPS}

Measurement invariance is a property that reflects the constancy of a measured construct between groups or across time. Traditionally, three levels of measurement invariance are tested: (1) configural, (2) metric and (3) scalar. They reflect the equivalency of the (1) measured constructs, (2) factor loadings and (3) item intercepts across groups (Meredith, 1993). In other words, testing measurement invariance verifies whether the constructs between studied groups are comparable.

In this study, it was decided to verify whether the sexual well-being construct measured by the SSWBS is comparable between the study groups. For this purpose, multiple group confirmatory factor analysis (MGCFA) was used. Due to the differences in the used scales, responses of the transgender people were converted from a 1-4 scale to the 1-7 scale $(1=1,2=3,3=5,4=7)$. The analysis confirmed the construct invariance across study groups. Metric and
Short Sexual Well-Being Scale 
Table 1

Results of the confirmatory factor analysis: goodness of fit measures and internal consistency $(N=322)$

\begin{tabular}{|c|c|c|c|c|c|c|c|c|c|}
\hline \multirow[t]{2}{*}{ Models } & \multirow[t]{2}{*}{ Sample } & \multirow{2}{*}{$\chi^{2}$} & \multirow[t]{2}{*}{$p$} & \multirow[t]{2}{*}{ CFI } & \multirow[t]{2}{*}{ TLI } & \multirow[t]{2}{*}{ SRMR } & \multirow[t]{2}{*}{ RMSEA } & \multicolumn{2}{|c|}{ RMSEA $90 \% \mathrm{Cl}$} \\
\hline & & & & & & & & LLCI & ULCI \\
\hline $\begin{array}{l}\text { One factor model } \\
\text { (4-point scale) }\end{array}$ & Transgender & 12.20 & .032 & .969 & .938 & .043 & .114 & .031 & .197 \\
\hline $\begin{array}{l}\text { One factor model } \\
\text { (4-point scale) with } \\
\text { error covariance* }^{*}\end{array}$ & Transgender & 7.02 & .135 & .987 & .967 & .033 & .082 & .001 & .181 \\
\hline $\begin{array}{l}\text { One factor model } \\
\text { (7-point scale) }\end{array}$ & Cisgender & 19.00 & .002 & .966 & .932 & .035 & .115 & .063 & .172 \\
\hline $\begin{array}{l}\text { One factor model } \\
\text { (7-point scale) with } \\
\text { error covariance* }^{*}\end{array}$ & Cisgender & 8.50 & .075 & .989 & .973 & .026 & .073 & .001 & .142 \\
\hline
\end{tabular}

Note. ${ }^{*}$ Error covariance set between items 3 and 4.

Table 2

Results of the confirmatory factor analysis: factor loadings $(N=322)$

\begin{tabular}{|c|c|c|c|c|}
\hline \multirow[t]{2}{*}{ Items } & \multicolumn{2}{|c|}{$\begin{array}{l}\text { Transgender sample } \\
\quad(4 \text {-point scale) }\end{array}$} & \multicolumn{2}{|c|}{$\begin{array}{l}\text { Cisgender sample } \\
\text { (7-point scale) }\end{array}$} \\
\hline & Estimate & Standardized & Estimate & Standardized \\
\hline $\begin{array}{l}\text { 1. The frequency of my sexual relations is } \\
\text { satisfactory for me }\end{array}$ & .80 & .77 & 1.16 & .78 \\
\hline 2. There is nothing disturbing in my sex life & .22 & .32 & 0.90 & .64 \\
\hline 3. There's a lot of physical pleasure in my sex life & .64 & .67 & 1.28 & .90 \\
\hline 4. I consider myself sexually fulfilled & .58 & .61 & 0.82 & .56 \\
\hline 5. I have no trouble realizing my sexual fantasies & .91 & .99 & 1.10 & .62 \\
\hline
\end{tabular}

thus scalar invariances were not confirmed. For more detailed information see Table 3.

\section{RELIABILITY}

Cronbach's $\alpha$ and McDonald's total $\omega$ (Gerymski $\&$ Krok, 2019) were used to evaluate the internal consistency of the SSWBS. Measures indicate good reliability of both versions of the scale. Removing any of the items did not increase the value of the reliability coefficients. For more detailed information see Table 4.

\section{VALIDITY}

The validity of the SSWBS scale was verified using two methods: the method of content validity and criterion validity. In order to verify the relevance of the SSWBS, the content validity ratio (CVR; Lawshe, 1975) was used. 10 researchers in the field of sexology, quality of life and health psychology were asked to assess how essential the scale questions are to the whole questionnaire. Before assessing the questions, the judges were introduced to the concept of sexual well-being. CVR and CVI (content validity index) measures calculated on the gathered results present positive values. This allows us to state that all questions were accurate from the theoretical point of view. For more detailed information, see Table 5 .

Criterion validity of SSWBS was measured using Pearson's $r$ correlation coefficient. It was decided to verify the relationship between sexual well-being with other related constructs: self-esteem, life satisfaction and sexual satisfaction. Data used in this analysis were collected only from the transgender people.

The analysis indicated a significant relationship between sexual well-being and other variables. The SSWBS summary score was positively related to self- 
esteem (weak effect size), life satisfaction (moderate effect size) and sexual satisfaction (strong effect size). Table 6 presents more detailed information about the relationship between the SSWBS items and constructs used to test the validity of the questionnaire.

\section{DISCUSSION}

The current study aimed to validate the Short Sexual Well-Being Scale (SSWBS) - a short questionnaire made in accordance with the sexual well-being concept. For this purpose, confirmatory factor analysis, reliability analysis using alpha and total omega coefficients, and two measures of validity (content and criterion validity) were used on a total sample of 311 participants - 111 transgender people and 211 cisgender people. The results indicate that both versions of the SSWBS have good psychometric properties.

Confirmatory factor analysis showed an acceptable goodness of fit to the data in both studies. Most coefficients indicate a good fit even without the use of modification indices. Due to the fact that the size of the cisgender group exceeds 200, these results should be taken into account when drawing conclusions from the CFA. This is also indicated by factor loadings, which show better properties of the 7-point scale.

Multiple group confirmatory factor analysis confirmed the construct invariance across studied groups. The presented results verified that the same items of the SSWBS can be used to measure the construct of sexual well-being among cisgender and transgender people. MGCFA results did not confirm the metric and scalar invariances of the two tested models. Metric non-invariance might suggest that the construct of sexual well-being might have a different meaning across groups. Therefore, the relationships between sexual well-being (as a latent variable) and SSWBS items might differ between cisgender and transgender people. Perhaps the hierarchy of the sexual well-being construct is different in tested groups due to the different cultural norms and gender identity in the studied groups. This should be verified in future studies. Metric non-invariance can also be caused by the artificially recoded responses of transgender people. At the present moment, the analyses do not allow the use of mean comparisons between the group of cisgender and transgender people. For further verification of the measurement invariance, additional tests should be carried out using the same version of the SSWBS scale.

The SSWBS presented good reliability among both transgender and cissexual people. The reliability values of the alpha and total omega coefficients exceeded the .70 threshold value. This indicates that all versions of the examined scale are good measures of the sexual well-being constructs.

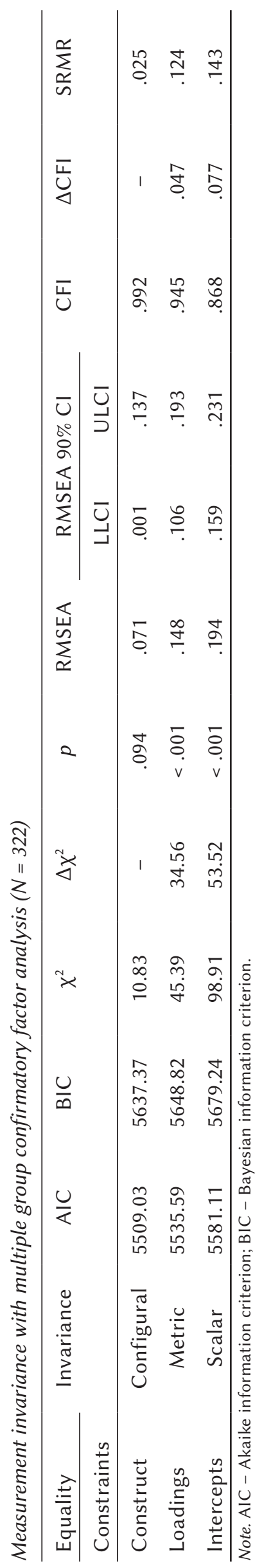

Short Sexual Well-Being Scale 
Table 4

Results of the reliability analysis $(N=322)$

\begin{tabular}{|c|c|c|c|c|}
\hline \multirow[t]{2}{*}{ Items } & \multicolumn{2}{|c|}{$\begin{array}{l}\text { Transgender sample } \\
\quad \text { (4-point scale) }\end{array}$} & \multicolumn{2}{|c|}{$\begin{array}{l}\text { Cisgender sample } \\
\text { (7-point scale) }\end{array}$} \\
\hline & $\alpha$ & $\omega_{t}$ & $\alpha$ & $\omega_{t}$ \\
\hline \multicolumn{5}{|l|}{$\begin{array}{l}\text { 1. The frequency of my sexual relations is satisfactory } \\
\text { for me }\end{array}$} \\
\hline \multicolumn{5}{|l|}{ 2. There is nothing disturbing in my sex life } \\
\hline 3. There's a lot of physical pleasure in my sex life & .80 & .82 & .83 & .84 \\
\hline \multicolumn{5}{|l|}{ 4. I consider myself sexually fulfilled } \\
\hline 5. I have no trouble realizing my sexual fantasies & & & & \\
\hline
\end{tabular}

\section{Table 5}

Results of the validity analysis: CVR and CVI measures

\begin{tabular}{lcc}
\hline Items & CVR & CVI \\
\hline 1. The frequency of my sexual relations is satisfactory for me & .99 \\
2. There is nothing disturbing in my sex life & .60 \\
3. There's a lot of physical pleasure in my sex life & .80 & .80 \\
4. I consider myself sexually fulfilled & .99 \\
5. I have no trouble realizing my sexual fantasies & .60 \\
\hline
\end{tabular}

Note. CVI is the mean of the CVR values of the retained items.

Table 6

Results of the validity analysis: Pearson's $r$ correlation $(N=111)$

\begin{tabular}{|c|c|c|c|c|c|c|}
\hline & \multicolumn{6}{|c|}{ Transgender sample } \\
\hline & \multicolumn{2}{|c|}{ Self-esteem } & \multicolumn{2}{|c|}{ Life satisfaction } & \multicolumn{2}{|c|}{ Sexual satisfaction } \\
\hline & $r$ & $p$ & $r$ & $p$ & $r$ & $p$ \\
\hline SSWBS - Total score & .29 & .002 & .41 & $<.001$ & .67 & $<.001$ \\
\hline SSWBS - Item 1 & .17 & .075 & .33 & $<.001$ & .42 & $<.001$ \\
\hline SSWBS - Item 2 & .32 & .001 & .20 & .041 & .49 & $<.001$ \\
\hline SSWBS - Item 3 & .33 & $<.001$ & .38 & $<.001$ & .62 & $<.001$ \\
\hline SSWBS - Item 4 & .08 & .378 & .22 & .019 & .43 & $<.001$ \\
\hline SSWBS - Item 5 & .23 & .017 & .36 & $<.001$ & .58 & $<.001$ \\
\hline
\end{tabular}

Note. SSWBS - Short Sexual Well-Being Scale.

Validity testing also indicates good psychometric properties of the SSWBS. The values of CVR and CVI coefficients were positive, which indicates a good fit of scale items to the theoretical construct of sexual well-being. In addition, the SSWBS was significantly and positively associated with the three constructs used to measure its validity - self-esteem, life sat- isfaction, and sexual satisfaction. This confirms that the SSWBS items properly reflect the universe of the sexual well-being concept.

Data presented in the manuscript confirm the validity of the new definition of sexual well-being. The new concept tries to define sexual well-being in line with the WHO's sexual health definition - reflected 
as a state of balance in the physical, mental, emotional and social spheres (World Health Organization, 2006). The study suggests that frequency of sexual relations, sexual distress, physical sexual satisfaction, emotional sexual fulfilment and sexuality in the social sphere may be a good suggestion for a new operationalization of the concept of sexual well-being. In order to further verify this concept, more extensive research should be carried out using more extensive scales, measuring each of the five elements of the new definition of sexual well-being more accurately.

Despite the validity of the concept of sexual wellbeing proposed in the introduction, it is not complete. None of the cited theoretical models presents sexual well-being in a universal manner. The factors shaping this construct may depend on many variables, including those not directly related to sexual well-being. For example, older people (above 60 years of age) refer to their sexual well-being differently than younger people, e.g. they place greater emphasis on activities such as kissing, hugging or touching another person. On the other hand, younger people usually refer to their sexual well-being based on their perceived sexual satisfaction (Gott \& Hinchliff, 2003; Skałacka \& Gerymski, 2019; Watson et al., 2017). Touching, kissing and cuddling seem to be more mature and subtle forms of sexuality expression, which are not directly identified with sexual well-being, but are certainly a part of it. These components are closely related to the feeling of love towards another person. According to the available theories, they are not direct components of sexual well-being and should be treated separately. However, studies clearly show that they positively affect satisfaction with the sexual sphere of both older and younger people (Fricker \& Moore, 2002; Gerymski \& Skałacka, 2018; HaavioMannila \& Kontula; 1997; Kaestle \& Halpern, 2007). In future studies it should be verified to what extent the construct of sexual well-being is different from the construct of love.

The study also seeks to shed new light on the sexuality of transgender people. The results show that the new construct of sexual well-being is also stable among this group of people. It was proven that sexual well-being of transgender people is associated with their sense of self-esteem, life satisfaction and sex satisfaction - significant predictors of well-being and quality of life of transgender people (Bouman et al., 2016). The author of this manuscript hopes that this will encourage transgenderism researchers to consider the concept of sexual well-being in the search of predictors of transgender people's quality of life. Upcoming studies should verify the role of sexual well-being in shaping of the quality of life of transgender people, which might act as a significant covariant of its other predictors, such as transphobia, sex reassignment surgery or hormone replacement therapy.

\section{LIMITATIONS}

Despite its statistical strength, the study was not free from limitations. It was not possible to fully validate the SSWBS on the data gathered from transgender people, due to the small sample size of that group (Gerymski \& Krok, 2020). Even the surveyed cisgender sample is not representative. Only 111 transgender and 211 cisgender people were examined.

Also, the impact of sociodemographic variables was not controlled. Those variables can significantly differentiate the results of the respondents. The present study focused on the validation of the questionnaire measuring sexual well-being with an emphasis on the group of transgender people. Biomedical variables related to the gender reassignment process were measured. Due to the insufficient sample size, the results did not allow for the calculation of supplementary analyses. Sociodemographic variables, such as marital or professional status, were not measured. For future research, these variables should be taken into account.

Due to the use of a different response scale in the studied groups, it was not possible to directly compare the level of sexual well-being between transgender and cisgender people. It was not possible to conduct a supplementary study due to the current situation in Poland. The presented results were obtained before the outbreak of the COVID-19 pandemic. A pandemic is an unexpected and often long-lasting event that affects all spheres of our lives (Dymecka et al., $2020,2021)$. It can also affect the sexual sphere of our functioning. Some people may be less sexually active due to anxiety and stress related to the fear of COVID-19. On the other hand, people who are forced to stay in their households may be more sexually active because of boredom or more free time they can spend with their partner. Comparing the sample obtained during the coronavirus pandemic with that presented in the study would not be correct, because the fear of COVID-19 or variables related to it might act as significant covariates affecting the results of the respondents. Unfortunately, available Polish fear of COVID-19 questionnaires are still not fully validated (Dymecka et al., 2020, 2021) and none of them has been used in a sample of transgender people. Following the end of the COVID-19 pandemic, further research is planned to compare transgender and cisgender people's sexual well-being levels.

\section{CONCLUSIONS}

Overall, the presented scale shows good psychometric properties. Both versions of the scale can be used in the quantitative research, but it is recommended to use the 7-point version of the scale. The SSWBS is one of the first questionnaires constructed in accor-
Short Sexual Well-Being Scale 
dance with the sexual well-being concept. The scale was created in order to have access to a good questionnaire for pilot research on a group of transgender people. Psychometric validation has shown that it can also be used on a group of cisgender people, but direct comparisons between those groups are not recommended. The SSWBS provides new empirical evidence to investigate the non-hedonistic aspect of sexuality. It is also recommended to begin to construct a more comprehensive tool, which will make it possible to explore all spheres of sexual well-being more precisely and separately.

\section{ReFERENCES}

Bancroft, J., Long, J. S., \& McCabe, J. (2011). Sexual wellbeing: a comparison of US Black and White women in heterosexual relationships. Archives of Sexual Behavior, 40, 725-740. https://doi.org/10.1007/s10508010-9679-z

Bouman, W. P., Davey, A., Meyer, C., Witcomb, G. L., \& Arcelus, J. (2016). Predictors of psychological wellbeing among treatment seeking transgender individuals. Sexual and Relationship Therapy, 31, 359375. https://doi.org/10.1080/14681994.2016.1184754

Diener, E. D., Emmons, R. A., Larsen, R. J., \& Griffin, S. (1985). The Satisfaction with Life Scale. Journal of Personality Assessment, 49, 71-75. https:// doi.org/10.1207/s15327752jpa4901_13

Dymecka, J., Gerymski, R., \& Machnik-Czerwik, A. (2020). How does stress affect our life satisfaction during COVID-19 pandemic? Moderating mediation analysis of sense of coherence and fear of coronavirus. PsyArXiv. https://doi.org/10.31234/osf. io/3zjrx

Dymecka, J., Gerymski, R., \& Machnik-Czerwik, A. (2021). Fear of COVID-19 as a buffer in the relationship between perceived stress and life satisfaction. Health Psychology Report, in print.

Flora, D. B., \& Curran, P. J. (2004). An empirical evaluation of alternative methods of estimation for confirmatory factor analysis with ordinal data. Psychological Methods, 9, 466-491. https://doi. org/10.1037/1082-989X.9.4.466

Fricker, J., \& Moore, S. (2002). Relationship satisfaction: The role of love styles and attachment styles. Current Research in Social Psychology, 7, 182-204.

Gerymski, R. (2017). Influence of the sex reassignment on the subjective well-being of transgender men - results of the pilot study and discussion about future research. Przeglad Seksuologiczny, 16, 10-16.

Gerymski, R. (2018). Wsparcie i radzenie sobie ze stresem jako moderatory związku stresu i jakości życia osób transpłciowych [Support and coping as moderators of the relationship between perceived stress and the quality of life of transgender people]. Czasopismo Psychologiczne, 24, 607-616.
Gerymski, R., \& Krok, D. (2019). Psychometric properties and validation of the Polish adaptation of the Light Triad Scale. Current Issues in Personality Psychology, 7, 341-354. https://doi.org/10.5114/ cipp.2019.92960

Gerymski, R., \& Krok, D. (2020). A Polish adaptation of the Multidimensional Existential Meaning Scale: Internal structure, reliability, and validity. Roczniki Psychologiczne, 23, 173-190. https://doi. org/10.18290/rpsych20232-4

Gerymski, R., \& Skałacka, K. (2018). Czy intymność, namiętność i zobowiązanie kształtują satysfakcję seksualną seniorów? Wyniki badania eksploracyjnego [Do intimacy, passion and commitment shape the sexual satisfaction of seniors? Results of the exploratory study]. Seksuologia Polska, 16, 43-50.

Gott, M., \& Hinchliff, S. (2003). How important is sex in later life? The views of older people. Social Science \& Medicine, 56, 1617-1628. https:// doi.org/10.1016/s0277-9536(02)00180-6

Graf, A. S., \& Patrick, J. H. (2014). The influence of sexual attitudes on mid-to late-life sexual well-being: Age, not gender, as a salient factor. The International Journal of Aging and Human Development, 79, 55-79. Haavio-Mannila, E., \& Kontula, O. (1997). Correlates of increased sexual satisfaction. Archives of Sexual Behavior, 26, 399-419. https://doi.org/ 10.1023/A:1024591318836

Kaestle, C. E., \& Halpern, C. T. (2007). What's love got to do with it? Sexual behaviors of opposite-sex couples through emerging adulthood. Perspectives on Sexual and Reproductive Health, 39, 134-140. https://doi.org/10.1363/3913407

Katsikatsou, M., Moustaki, I., Yang-Wallentin, F., \& Jöreskog, K. G. (2012). Pairwise likelihood estimation for factor analysis models with ordinal data. Computational Statistics \& Data Analysis, 56, 42434258. https://doi.org/10.1016/j.csda.2012.04.010

Kim, H. Y. (2013). Statistical notes for clinical researchers: Assessing normal distribution (2) using skewness and kurtosis. Restorative Dentistry \& Endodontics, 38, 52-54. https://doi.org/10.5395/ rde.2013.38.1.52

Koğar, H., \& Koğar, E. Y. (2015). Comparison of different estimation methods for categorical and ordinal data in confirmatory factor analysis. Journal of Measurement and Evaluation in Education and Psychology, 6, 351-364. https://doi.org/10.21031/epod.94857

Kuhn, A., Bodmer, C., Stadlmayr, W., Kuhn, P., Mueller, M. D., \& Birkhäuser, M. (2009). Quality of life 15 years after sex reassignment surgery for transsexualism. Fertility and Sterility, 92, 1685-1689. https://doi.org/10.1016/j.fertnstert.2008.08.126

Kuiper, B., \& Cohen-Kettenis, P. (1988). Sex reassignment surgery: a study of 141 Dutch transsexuals. Archives of Sexual Behavior, 17, 439-457. https:// doi.org/10.1007/BF01542484 
Laumann, E. O., Paik, A., Glasser, D. B., Kang, J. H., Wang, T., Levinson, B., Moreira, E. D., Nicolosi, A. \& Gingell, C. (2006). A cross-national study of subjective sexual well-being among older women and men: Findings from the Global Study of Sexual Attitudes and Behaviors. Archives of Sexual Behavior, 35, 145-161. https://doi.org/10.1007/s10508-005-9005-3

Lawshe, C. H. (1975). A quantitative approach to content validity. Personnel Psychology, 28, 563-575. https://doi.org/10.1111/j.1744-6570.1975.tb01393.x

Leavitt, C. E., Lefkowitz, E. S., \& Waterman, E. A. (2019). The role of sexual mindfulness in sexual wellbeing, relational wellbeing, and self-esteem. Journal of Sex \& Marital Therapy, 45, 497-509. https://doi.org/10.1080/0092623X.2019.1572680

Li, C. H. (2016). Confirmatory factor analysis with ordinal data: Comparing robust maximum likelihood and diagonally weighted least squares. Behavior Research Methods, 48, 936-949. https:// doi.org/10.3758/s13428-015-0619-7

Lombardi, E. (2009). Varieties of transgender/transsexual lives and their relationship with transphobia. Journal of Homosexuality, 56, 977-992. https:// doi.org/10.1080/00918360903275393

Mastro, S., \& Zimmer-Gembeck, M. J. (2015). Let's talk openly about sex: Sexual communication, selfesteem and efficacy as correlates of sexual well-being. European Journal of Developmental Psychology, 12, 579-598. https://doi.org/10.1080/17405629.2015. 1054373

Meredith, W. (1993). Measurement invariance, factor analysis and factorial invariance. Psychometrika, 58, 525-543. https://doi.org/10.1007/BF02294825

Muthén, B., \& Kaplan, D. (1985). A comparison of some methodologies for the factor analysis of nonnormal Likert variables. British Journal of Mathematical and Statistical Psychology, 38, 171-189. https://doi.org/10.1111/j.2044-8317.1985.tb00832.x

Nemoto, T., Iwamoto, M., Perngparn, U., Areesantichai, C., Kamitani, E., \& Sakata, M. (2012). HIVrelated risk behaviors among kathoey (male-tofemale transgender) sex workers in Bangkok, Thailand. AIDS Care, 24, 210-219. https://doi.org/ 10.1080/09540121.2011.597709

Nomejko, A. (2010). Poczucie jakości życia a samoocena, płeć psychologiczna i satysfakcja seksualna. Praca magisterska [Sense of quality of life and self-esteem, psychological gender and sexual satisfaction. Master thesis]. University of Wrocław.

Öberg, K., Fugl-Meyer, K. S., \& Fugl-Meyer, A. R. (2002). On sexual well-being in sexually abused Swedish women: Epidemiological aspects. Sexual and Relationship Therapy, 17, 329-341. https://doi. org/10.1080/1468199021000017182

Ochnik, D., \& Slonim, G. (2020). Satisfaction with singlehood in never-married singles: The role of gender and culture. The Open Psychology Journal, 13, 17-26. https://doi.org/10.2174/1874350102013010017
Poteat, T., Wirtz, A. L., Radix, A., Borquez, A., Silva-Santisteban, A., Deutsch, M. B., Khan, S. I., Winter, S., \& Operario, D. (2015). HIV risk and preventive interventions in transgender women sex workers. The Lancet, 385, 274-286. https://doi.org/10.1016/S01406736(14)60833-3

Reisner, S. L., Mimiaga, M. J., Bland, S., Mayer, K. H., Perkovich, B., \& Safren, S. A. (2009). HIV risk and social networks among male-to-female transgender sex workers in Boston, Massachusetts. Journal of the Association of Nurses in AIDS Care, 20, 373-386. https://doi.org/10.1016/j.jana.2009.06.003 Rhemtulla, M., Brosseau-Liard, P. É., \& Savalei, V. (2012). When can categorical variables be treated as continuous? A comparison of robust continuous and categorical SEM estimation methods under suboptimal conditions. Psychological Methods, 17, 354-373. https://doi.org/10.1037/a0029315

Rosen, R. C., \& Bachmann, G. A. (2008). Sexual wellbeing, happiness, and satisfaction, in women: The case for a new conceptual paradigm. Journal of Sex \& Marital Therapy, 34, 291-297. https://doi. org/10.1080/00926230802096234

Rosenberg, M. (1979). Conceiving the Self. Basic Books.

Ryan, R. M., \& Deci, E. L. (2001). On happiness and human potentials: a review of research on hedonic and eudaimonic well-being. Annual Review of Psychology, 52, 141-166. https://doi.org/10.1146/annurev.psych.52.1.141

Skałacka, K., \& Gerymski, R. (2019). Sexual activity and life satisfaction in older adults. Psychogeriatrics, 19, 195-201. https://doi.org/10.1111/psyg. 12381

Stephenson, K. R., \& Meston, C. M. (2010). Differentiating components of sexual well-being in women: Are sexual satisfaction and sexual distress independent constructs? The Journal of Sexual Medicine, 7, 2458-2468. https://doi.org/10.1111/j.17436109.2010.01836.x

Štulhofer, A., Jurin, T., Graham, C., Enzlin, P., \& Træen, B. (2019). Sexual well-being in older men and women: Construction and validation of a multidimensional measure in four European countries. Journal of Happiness Studies, 20, 2329-2350. https:// doi.org/10.1007/s10902-018-0049-1

Watson, W. K., Stelle, C., \& Bell, N. (2017). Older women in new romantic relationships: understanding the meaning and importance of sex in later life. The International Journal of Aging and Human Development, 85, 33-43. https://doi. org/10.1177/0091415016680067

World Health Organization (2006). Defining sexual health. Retrieved from http://www.who.int/reproductivehealth/topics/sexual_health/sh_definitions/en/
Short Sexual Well-Being Scale 
APPENDIX 1

\section{SHORT SEXUAL WELL-BEING SCALE}

Indicate to what extent you agree with each statement using the following scale:

1 - I completely disagree

2 - I disagree

Rafał Gerymski

3 - I somewhat disagree

4 - I neither agree nor disagree

5 - I somewhat agree

6 - I agree

7 - I completely agree

1. The frequency of my sexual relations is satisfactory for me

2. There is nothing disturbing in my sex life

3. There's a lot of physical pleasure in my sex life

4. I consider myself sexually fulfilled

5. I have no trouble realizing my sexual fantasies 
APPENDIX 2

\section{KRÓTKA SKALA DOBROSTANU SEKSUALNEGO}

Wskaż, w jakim stopniu zgadzasz się z każdym stwierdzeniem za pomocą następującej skali:

1 - zupełnie nie zgadzam się

2 - nie zgadzam się

3 - raczej nie zgadzam się

Short Sexual

4 - ani się zgadzam, ani nie zgadzam

5 - raczej zgadzam się

6 - zgadzam się

7 - całkowicie zgadzam się

1. Częstotliwość moich kontaktów seksualnych jest dla mnie zadowalająca

2. Nie ma w moim życiu seksualnym niczego niepokojącego

3. Moje życie seksualne sprawia mi dużo fizycznej przyjemności

4. Uważam się za osobę spełnioną seksualnie

5. Nie mam kłopotów z realizowaniem swoich fantazji seksualnych 